\title{
Comunicação empresarial versus comunicação organizacional: novos desafios teóricos*
}

\author{
Onésimo de Oliveira Cardoso**
}

SuMÁrio: 1. Introdução; 2. Comunicação empresarial: defasagens e limites; 3. Limites do esquema tradicional da comunicação; 4. Comunicação organizacional: uma nova dimensão; 5. Estratégia da organização e estratégia de comunicação; 6. Conclusão.

SUMMARY: 1. Introduction; 2. Business communication: anachronisms and limitations; 3. Limitations of the traditional communication scheme; 4. Organizational communication: a new dimension; 5. Organization strategy and communication strategy; 6 . Conclusion.

Palavras-Chave: comunicação empresarial; comunicação organizacional; fundamentos teóricos.

KEY WORDS: business communication; organizational communication; theoretical foundations.

O papel da comunicação e da informação no ambiente organizacional, sem dúvida, tem despertado o desenvolvimento de diferentes enfoques conceituais e teóricos. Todavia, a não-aplicabilidade de processos comunicativos relevantes no ambiente das organizações, principalmente em situações complexas, leva-nos a refletir sobre um novo conceito de comunicação organizacional. Neste artigo, analisamos fundamentos teóricos da comunicação de Habermas e de Cohn e, principalmente, algumas contribuições do teórico da complexidade, Dominique Genelot, para o embasamento da comunicação organizacional como um elemento estratégico na realização dos objetivos e da intencionalidade das organizações, na tentativa de superar os limites dos enfoques

* Artigo recebido em dez. 2005 e aceito em ago. 2006.

** Doutor em comunicação pela Universidade de Münster (Alemanha); professor adjunto da FEA/PUC-São Paulo, Programa de Estudos Pós-Graduados em Administração; assessor da PósGraduação e Pesquisa na Unicsul. Endereço: Rua Capote Valente, 1335/41 — CEP 05409-003, São Paulo, SP, Brasil. E-mail: o-cardoso@uol.com.br. 
reducionistas do conceito tradicional de comunicação empresarial, influenciado principalmente pela visão instrumental da comunicação sustentada pela teoria da informação e pelos corpora teóricos que se inspiraram em tal conceito e que com base nele se desenvolveram.

\section{Business communication versus organizational communication: new theoretical challenges}

The role of communication and information in the organizational environment has definitely triggered the development of different conceptual and theoretical approaches. However, the non-applicability of relevant communicative processes in such environments, mainly within complex situations, makes researchers think about a new concept of organizational communication. In this article, the theoretical foundations of communication by Habermas and by Cohen, as well as some contributions of Dominique Genelot, will be analyzed. These foundations are to be used as a basis for organizational communication, as well as a strategic element for accomplishing the goals and intentionality of organizations, trying to overcome the limits of reductionist approaches of the traditional concept influenced mainly by an instrumental view of communication and sustained by the theory of information and by theoretical corpora.

\section{Introdução}

O objetivo deste artigo é refletir sobre os limites da abordagem da comunicação empresarial e analisá-los, tendo como pano de fundo as idéias de Genelot $(2001)^{1}$ sobre estratégia da comunicação num ambiente de incerteza e complexidade. A perspectiva é desenvolver alguns fundamentos de uma nova dimensão da comunicação organizacional e enriquecer os seus aportes teóricos. Serão aqui recuperados os principais elementos dos fundamentos teóricos de Genelot (2001) sobre informação e comunicação. Para problematizálos, serão também utilizados autores da área de comunicação, como Habermas e Luhmann (1972), Habermas (1981), Cohn (2001), Mattelart (1994), Braman (1989), Luhmann (1990), Castells (1997), Lévy (1996 e 2000), Put-

\footnotetext{
${ }^{1}$ Dominique Genelot, presidente do Insep-Consulting, Entreprise de Conseil en Management. Autor do livro Manager dans la complexité. Réflexions à l'usage des dirigeants. Téorico da abordagem francesa da complexidade, juntamente com Edgar Morin, René Passet e Jean-Louis Le Moigne. Apesar de, na Europa, Genelot ser um nome expressivo quando se trata da reflexão a respeito do fenômeno da comunicação e administração, no Brasil, ainda é um autor desconhecido nos textos acadêmicos na área da administração.
} 
nam (1982), Putnam e outros (2004), Taylor (1993) e Tompkins e WancaThibault (2001).

Desenvolveremos uma análise teórico-crítica com certa liberdade, por entendermos que a esfera metodológica não é um campo sagrado que gera uma verdade inquestionável. Acreditamos que no máximo se pode alcançar a construção de pensamentos mais verdadeiros por meio do pluralismo metodológico que dá conta da multiplicidade de arranjos discursivos ou de combinatórias, de efeitos de sentido e de dimensões figurativas e aleatórias que proliferam na atualidade.

Para se chegar a um nível compreensivo da construção social da realidade, recorre-se à interpretação, embora se saiba que a realidade como tal não depende dela para existir: ela existe com ou sem intérprete. A realidade conhecida é inevitavelmente aquela interpretada. Por meio da hermenêutica, é possível perceber que a interpretação é inevitável e, conseqüentemente, rompe-se o círculo vicioso do objeto-sujeito-objeto e se amplia no campo da compreensão, da comensurabilidade e, portanto, da intersubjetividade. A reflexão hermenêutica possibilita descobrir as entrelinhas além dos limites, os contextos além do texto, as significações além da palavra, conforme salienta Santos (1989).

A informação e os processos de comunicação sempre estiveram presentes na evolução das estratégias empresariais e na própria evolução das organizações. Por isso, hoje, muito mais do que em épocas passadas, torna-se necessário entender a complexidade que envolve a informação e os processos comunicacionais na gestão estratégica das organizações. Afinal, vivemos numa era de ritmo acelerado de transformações e contextos cada vez mais complexos, onde as organizações precisam buscar novas lógicas de gestão para enfrentar a competitividade.

No âmbito dessas novas lógicas, salientamos exatamente a importância da informação e comunicação como instrumentos e processos poderosos para a realização das potencialidades estratégicas e para a ampliação e integração das estruturas organizacionais. É por meio desses instrumentos que as organizações desenvolvem funções, tomam decisões e estabelecem contatos com clientes, fornecedores e parceiros. Isso significa que as organizações precisam repensar, complementar e aprimorar seus referenciais teóricos e metodológicos tradicionais, formulando e disseminando estratégias que levem em conta os processos comunicacionais como suportes eficazes e competentes para o agir e existir delas. Às vezes, uma organização é definida de maneira simplista, como um grupo humano composto por especialistas que trabalham em conjunto em uma tarefa comum. Uma organização é mais que isso: é uma unidade coletiva de ação formada para perseguir fins específicos e é dirigida 
por um poder que estabelece a autoridade, determina o status e o papel de seus membros. Uma empresa, um hospital, uma universidade, por exemplo, são organizações.

Uma organização apresenta normalmente duas configurações: primeiro, situa-se em um conjunto societal como expressão particular e concreta de um sistema de ação histórica; segundo, é uma atividade regulada por decisões que emanam da sua filosofia. Neste artigo, trataremos a organização mais especificamente como um "conjunto de relações de ordem estrutural (direção, planejamento, operação e controle), que mantém uma empresa em funcionamento" (Sandroni, 1996:369-370). Apesar dessa especificidade, compreendemos que a comunicação organizacional abrange todo tipo de organização social — pública ou privada.

A informação e a comunicação têm, cada vez mais, assumido um papel importante na prática de gestão empresarial no mundo globalizado. O chamado campo de estudo da comunicação empresarial tem sido, nas últimas décadas, a área de fundamentação teórico-conceitual e de desenvolvimento de práticas comunicacionais que permite às empresas desenvolverem suas estratégias de negócios. No entanto, as transformações constantes ocorridas no campo sociopolítico e no econômico e o avanço significativo de tecnologias de informação têm colocado em xeque os fundamentos da disciplina comunicação empresarial e permitido a elaboração de novos enfoques teóricos, epistemológicos e técnicos que mudam significativamente a maneira de entendermos a informação e a comunicação na gestão dos negócios. Tais enfoques configuram a nova dimensão da comunicação organizacional de que estamos tratando, uma dimensão que deixa claro que não se pode mais aceitar que o processo de comunicação, mantendo-se com seus modelos homogeneizados, verticalizados e com ênfase na instrumentalidade da comunicação, segundo os fundamentos matemáticos, cibernéticos e sistêmicos, seja a maneira mais pertinente para responder aos desafios da gestão estratégica das organizações em tempo de globalização (Daniels, Spiker e Papa, 1997; Fossá, 1997; Kunsch, 1997; Schuler, 2004; Scroferneker, 2000; Tompkins e Wanca-Thibault, 2001; Rego, 1986).

Pensar na comunicação e na informação como elementos das estratégias de gestão, no contexto contemporâneo, é um desafio que precisa ultrapassar as fórmulas superadas que estão comprometidas com a racionalidade instrumentalizada e o monopólio da verdade, para que se alcancem formas de colocar o ser humano em pauta, valorizando a capacidade criadora do indivíduo, sem desprezar a subjetividade e a afetividade, e vendo a organização como resultado de um processo dialógico com o meio ambiente. 


\section{Comunicação empresarial: defasagens e limites}

Para se superar os limites da comunicação empresarial tradicional e dos enfoques instrumentais da comunicação organizacional, é necessário que se entenda a comunicação como um processo estratégico para a ação em uma realidade plural, dinâmica e complexa, que visa a provocação de comportamentos inovadores, criativos e dinâmicos do ponto de vista estratégico e que funciona, de maneira democrática, como disseminadora dos objetivos e dos valores culturais da empresa para públicos internos e externos.

$\mathrm{O}$ mundo globalizado tem produzido mudanças significativas na gestão dos negócios. Novas práticas administrativas e gerenciais têm surgido nas últimas décadas, não só como resultado da busca incessante pela produtividade, qualidade e satisfação do cliente, mas também em conseqüência da preocupação com o meio ambiente. E tanto a busca pela excelência empresarial quanto a preocupação com o consumidor e com o futuro do planeta têm produzido novas concepções de gestão de negócios. São mudanças econômicas com transformações significativas para os mercados e para os relacionamentos entre seres humanos dentro e fora da empresa.

Têm ocorrido mudanças céleres em diferentes campos do conhecimento que nos desafiam a entender as alterações de abordagens e "paradigmas": as novas tecnologias, por exemplo, inauguraram uma nova lógica - a lógica da rede (Castells, 1997), da realidade virtual, do ciberespaço (Lévy, 1996 e 2000) e da procura individualizada pelo cliente em substituição ao marketing de massa. A realidade virtual é capaz de aproximar pessoas de todas as partes do mundo pela informação e, ao mesmo tempo, isolar os indivíduos do convívio profissional, modificar as relações de trabalho e as formas de consumo e transformar a concepção dos conceitos de trabalho e de empresa.

Nas abordagens que tradicionalmente dominam no âmbito da comunicação empresarial, o objetivo primordial da empresa é buscar a melhor mensagem e o melhor meio para estabelecer contatos com os públicos-alvo, visando mudar modos de pensar, influenciar decisões, modificar os subordinados para o alcance dos objetivos organizacionais, anunciar eventos, vender alguma coisa e eliminar conflitos. Entretanto, essa visão - que já não se sustentava no passado - não se sustenta de maneira eficiente nos dias atuais pelo seu reducionismo e simplismo diante da complexidade do mundo das organizações (Casali, 2004; Fossá, 1997; Putnam et al., 2004; Tompkins e Wanca-Thibault, 2001).

O conceito de comunicação empresarial tornou-se tão esvaziado que o melhor caminho é destruir seu repertório e pensar na comunicação e na informação como instrumentos de gestão que criam e desenvolvem uma cultura 
organizacional, na qual todos se sintam envolvidos e, de alguma forma, participantes (Genelot, 2001).

Lévy (2000) defende que estamos assistindo, na entrada do novo milênio, ao nascimento da cibercultura, uma transformação radical nas culturas humanas, ocasionada por uma rede digital que conecta tudo a todos: o ciberespaço. Nesse contexto, as culturas nacionais fundem-se em uma cultura cibernética e globalizada, mantendo-se, todavia, a velha dicotomia entre países pobres e ricos. Mas o autor acredita que o ciberespaço também pode ser um agente de democratização ao permitir que textos e imagens de todos os tipos circulem em grande escala no mundo inteiro. Como a cibercultura, com seu caráter democrático, leva-nos a questionar as abordagens centralizadoras e verticais dos processos comunicativos, essas idéias sem dúvida nos ajudam a pensar na democratização da comunicação no ambiente das organizações.

O domínio do enfoque mecanicista da organização desenvolve uma racionalidade funcional ou instrumental, encorajando as pessoas a obedecerem a ordens e a manterem a sua posição, em vez de se interessarem por desafios e questionarem aquilo que estão fazendo. Esse tipo de racionalidade contrasta com um pensamento reflexivo e auto-organizador que incentiva as pessoas a questionarem a propriedade daquilo que estão fazendo e a modificarem sua ação, ajustando-a a novas situações.

As transformações estruturais que ocorrem no mundo e na sociedade provocam profundas alterações na forma de relacionamento das organizações: para sobreviverem e tornarem-se competitivas no mundo globalizado, elas necessitam criar mecanismos que auxiliem no processo de transformação e que permitam, em um contexto de redes de informação, maior integração com os diversos agentes com que interagem.

No ambiente empresarial, a ênfase que era dada à produção mudou para a ênfase ao consumidor. Portanto, a empresa precisa, da melhor forma possível, comunicar-se com a comunidade, com o cliente, com os agentes governamentais, com os fornecedores, enfim, com outras organizações e/ou agentes que também atuam nesse universo ou rede. A comunicação assume, assim, um papel fundamental na absorção e divulgação dos novos paradigmas empresariais, podendo agir como poderosa ferramenta estratégica de gestão.

A dimensão estratégica que a comunicação vem assumindo nas organizações, sendo parte da cultura organizacional, modifica paulatinamente antigos limites. Não mais se restringe à simples produção de instrumentos de comunicação: ela assume um papel muito mais abrangente, que se refere a tudo que diz respeito à posição social e ao funcionamento da organização, desde seu clima interno até suas relações institucionais. Uma estratégia de comunicação é algo intrínseco à estratégia global da organização. Expressando 
de forma mais radical, pode-se afirmar que comunicação e organização constituem um único fenômeno, isto é, comunicação é organização e organização é comunicação: os dois processos são isomórficos (Putnam et al., 2004; Taylor, 1993). Nos tópicos seguintes aprofundaremos essa reflexão.

\section{Limites do esquema tradicional da comunicação}

A teoria da informação surgiu em fins da década de 1940 como resposta à necessidade de entender a informação que se apresentava como matéria-prima para a tomada de decisões gerenciais. Baseada na teoria matemática da informação, desenvolvida por Shannon e Weaver (1949), constitui até os dias atuais uma abordagem relevante. É uma teoria sobre a transmissão das mensagens. O modelo comunicativo proposto por eles é o seguinte: existe uma fonte de informação, a partir da qual é emitido um sinal, por meio de um aparelho transmissor; esse sinal viaja por um canal, ao longo do qual pode ser perturbado por um ruído; quando sai do canal, o sinal é captado por um receptor que o converte em mensagem que, como tal, é compreendida pelo receptor.

Quando os autores formularam a teoria matemática da comunicação, Claude Shannon trabalhava para a Bell Telephone e era professor de ciências no Massachusetts Institute of Technology e Warren Weaver era o vice-presidente da Fundação Alfred P. Sloan. Essa teoria estabeleceu que a informação pode incluir mensagens transmitidas por qualquer mídia. O seu objetivo era encontrar o meio mais rápido e o modo mais eficiente para obter uma mensagem de um ponto a outro.

A teoria da informação compreende os problemas de transmissão de informação e sua preocupação reside no interesse por código, canal, capacidade, ruído, redundância e outras propriedades estatísticas da linguagem. Esses problemas são primariamente sintáticos e a teoria da informação não está interessada no significado dos símbolos da mensagem, pois sua base são os sinais. O sinal, para ser transmitido, precisa de um meio físico que é denominado canal. Para transformar o sinal em mensagens, usamos um código (sistema que estabelece correspondência entre um sinal e uma mensagem). O ruído é o que perturba o processo de transmissão e, para evitá-lo, precisamos tornar o código redundante, ou seja, introduzir elementos de controle para se conseguir maior eficácia comunicacional. Todavia, mesmo que seja possível transmitir uma série de símbolos com exatidão sintática, eles permaneceriam desprovidos de significação se o emissor e o receptor não tivessem antecipadamente concordado sobre a sua significação. Nesse sentido, toda a informação compartilhada pressupõe uma convenção semântica. 
Apesar dos seus limites, a teoria da informação surge num contexto onde já havia ficado claro que os processos de comunicação ocupavam um lugar mais estratégico na sociedade, uma vez que a informação havia se tornado matéria-prima no campo da produção e não somente no da circulação. No entanto, o estudo do campo da produção se mantinha preso a uma dispersão disciplinar e metodológica que impossibilitava conhecer objetivamente o que ali ocorria. Nesse contexto, surge a teoria da informação como capaz de ordenar o campo da pesquisa e delimitar os objetos. A comunicação encontrou nessa teoria um marco de conceitos precisos, de delimitação metodológica e inclusive de propostas operativas capazes de fornecer um modelo científico abalizado pela seriedade da matemática e pelo prestígio da cibernética.

Muito embora tal teoria tenha se revelado como um marco de conceitos precisos e operacionais, Genelot (2001) questiona o esquema de Shannon e Weaver (1949), mostrando que, apesar desse modelo ter impregnado a cultura coletiva de nosso tempo e ter se tornado obrigatório para todos os que estudam e realizam a comunicação com seu modelo de transmissão codificado de informação, ele apresenta limites e não garante a eficácia do processo comunicativo. Contudo, não deixa de destacar os seguintes elementos nesse processo informacional:

V noção de emissor e receptor;

v distinção entre sinal e mensagem;

v existência de uma codificação para transformar a mensagem em sinal de emissão e de uma codificação para transformar o sinal em mensagem de recepção;

V noção de canal de transmissão;

、 ruídos na transmissão e correção de enganos pelo sistema de controle por retroalimentação.

Em resumo, Shannon e Weaver (1949) afirmam que, se houver univocidade entre codificação e decodificação e eliminação dos ruídos na transmissão por um sistema de retroalimentação, teremos uma "boa" comunicação. Todavia, isso não ocorre de maneira tranqüila. Mesmo os sinais sendo transmitidos com correção, não há nenhuma segurança quanto à boa transmissão de um significado. Para se trabalhar o significado, é necessário entender pelo menos duas funções da linguagem: a comunicação e a construção de um significado. 
Para Genelot (2001), o receptor analisa uma mensagem de acordo com três componentes: literal, situacional e interpretativo. O componente literal é a propriedade das palavras em evocar uma significação. A comunicação supõe a esse nível o uso de um mesmo sistema de codificação. Já o componente situacional recupera os lugares, o tempo e as pessoas que estão envolvidas na situação. Não há correspondência automática entre as palavras e a sensação. As condições nas quais as palavras são expressas ou nas quais são ouvidas condicionam a sua sensação. O componente interpretativo, por sua vez, requer uma confrontação com as estruturas de representações de intenções, de esquemas cognitivos para poder liberar uma significação. Constata-se, por meio dessa análise, que a elaboração do sentido em processo de comunicação não é, ao contrário do que se supõe, algo simples e direto. É um processo complexo, cheio de imprevistos, sutilezas e recursividade entre o emissor e o receptor.

Pode-se mesmo perguntar se um dos interesses principais dos interlocutores no uso da linguagem não seria o de apresentar lacunas, ambigüidades que necessitem de ajustes que fariam avançar o diálogo comunicacional. $\mathrm{O}$ modelo de comunicação de Shannon e Weaver (1949), que tem se mostrado excelente para fazer progredir as tecnologias, não pode absolutamente dar conta dessa complexidade. É um modelo que não inclui as condições sociais de produção do sentido e que, desse modo, anulou a possibilidade de análise das lutas pelo poder, isto é, pelo discurso que articula o sentido construído pela sociedade. Além disso, o modelo se sustenta em uma fragmentação do processo comunicativo, que destacaria a dimensão de transmissão da informação e de busca da eficiência que, por sua vez, é referendada pelo "rigor e critério científico" atribuído à teoria matemática. Nessa perspectiva, a comunicação é fundamentalmente mecanicista, e a seleção de canais, o processamento e a transmissão da informação são enfatizados. A comunicação, aí, é vista como um conduíte e as organizações como contêineres ou meros sistemas físicos (Casali, 2004; Putnam, 1982).

Assim, o emprego amplo da teoria da informação acabou reduzindo os problemas sociais a problemas técnicos e dissolveu o político, pois nesse modelo não há lugar para as contradições e os conflitos. O uso dessa abordagem foi perdendo sua significação à medida que se percebeu que todo conhecimento científico possui uma parte observável da realidade e outra interpretativa e que a realidade é mais rica do que as interpretações que fazemos dela e que, portanto, não existe verdade inquestionável.

A insuficiência teórica do modelo tradicional de informação, com todas as suas variações e desmembramentos, no ambiente das organizações, levanos a refletir acerca de novas possibilidades teóricas e epistemológicas do papel da comunicação no ambiente organizacional. 


\section{Comunicação organizacional: uma nova dimensão}

A comunicação é um fato nas organizações, ou seja, não existe nenhuma organização sem uma prática comunicativa, ainda que os processos comunicativos não sejam institucionalizados. Eles são essenciais para a operação da entidade e estão intimamente vinculados às formas de significar, valorar e expressar uma organização, isto é, ao processo comunicacional e constitutivo da cultura da organização, e de sua identidade, configurando imagens reconhecidas por seus diversos públicos internos e externos. A comunicação pode ser entendida, então, como um alicerce que dá forma à organização, fazendo-a ser aquilo que ela é. Porém, isso não significa que a comunicação seja algo autônomo, porque ela será sempre correspondente à forma de ser daquilo que a engendra, neste caso, a empresa ou instituição.

Convém relembrar que as grandes transformações que têm ocorrido (globalização e abertura econômica, processos de privatização, aumento da produtividade e aceleração da competitividade, revolução tecnológica e impacto das tecnologias de informação) vêm produzindo desafios para as organizações quanto às suas estratégias de gestão (Mattelart, 1994; McGee e Prusak, 1995; Putnam et al., 2004). No âmbito interno das organizações empresariais, as relações com os empregados, os diferentes estilos administrativos, assim como as ações humanas, demandam novos rumos de gestão que superem os modelos lineares, verticais e impositivos e alcancem novas formas de ação administrativa que envolvam e valorizem o trabalho em equipe baseado na maior participação e autonomia dos envolvidos. Na esfera externa, as relações empresariais demandam propostas inovadoras para as atividades de serviço, de mercado e de marketing e especial atenção para as questões culturais, éticas e sociais que envolvem as ações organizacionais.

Em qualquer desses âmbitos, faz-se evidente a presença de processos e ações de comunicação que não devem ser entendidos como complementos da estratégia organizacional, mas como componentes essenciais na construção de uma estratégia comum. Além disso, tais processos e ações são formadores da identidade cultural de qualquer organização e, por fim, da projeção de sua imagem (Genelot, 2001).

A comunicação organizacional necessita ser entendida, de maneira integral, como elemento que atravessa todas as ações de uma empresa ou organização e que configura, de forma permanente, a construção de sua cultura e identidade. Cada vez mais, torna-se claro como os processos de comunicação contribuem para desenvolver formas de inter-relação mais participativas e, portanto, mais comprometidas, dando maior flexibilidade às organizações como base de sua permanente transformação e facilitando sua interação soci- 
al de modo responsável para conjugar seus interesses com as condições culturais, econômicas e políticas nas quais se movem.

Lidar com esses aspectos é indispensável para qualquer organização. Quando uma organização compromete-se com uma perspectiva comunicacional estratégica, ou seja, trabalha no âmbito da nova dimensão da comunicação organizacional, ela reconhece não só novas maneiras de ver o trabalho, mas também as relações internas e os diversos processos de interação com seus variados públicos externos. Entender a organização como um ambiente comunicacional implica reconhecê-la nas múltiplas formas que tem de se apresentar aos seus diferentes públicos; implica, portanto, reconhecê-la como construtora de sentidos e de formas de ser que configuram a sociedade.

Assim, devemos buscar novas dimensões para a comunicação organizacional que a vejam como um processo amplo, que se confunde com a própria estratégia da organização, e não a restrinjam apenas aos fenômenos internos da organização ligados a setores e departamentos.

\section{Estratégia da organização e estratégia de comunicação}

Os novos desafios enfrentados pelas organizações, principalmente nas duas décadas passadas, mudaram significativamente o enfoque da comunicação empresarial para uma visão mais estratégica da comunicação que, neste artigo, estamos denominando comunicação organizacional.

Juntamente com o fenômeno da globalização, os processos macroeconômicos trazem como condição crucial para o gerenciamento das operações produtivas e comerciais a rápida difusão de novos meios de comunicação e tecnologias da informação. Tais dimensões técnicas, das quais a internet é um exemplo, potencializam a ação articulada de públicos mais amplos em termos econômicos e políticos, num leque que abrange consumidores em escala mundial, imprensa nacional e estrangeira, comunidades, acionistas, sindicatos, fornecedores e autoridades, entre outros. Sem dúvida, esses públicos, que antes eram descritos apenas como alvo nas práticas convencionais das empresas, passaram a ter importância estratégica para ajudar a organização a competir num ambiente em constante mutação (Castells, 1997; Davenport, 1998; Shapiro e Varian, 1999).

Nessa nova configuração macroeconômica, as organizações empresariais lidam com públicos com demandas não só de produtos e serviços, mas também com claras demandas de diálogo. Daí a necessidade de elas dedicarem suas estratégias à sociedade como somatório de públicos diversos e ao mercado como local da concorrência e do consumo. Essas estratégias estariam comprometidas com processos comunicacionais agregados às comunidades com seus membros, 
aos trabalhadores, às agências reguladoras que cobram das empresas eficiência e qualidade e aos consumidores cada vez mais exigentes e amparados pelos códigos de sua defesa.

A abertura comercial, a mudança do papel do Estado na economia, a desregulamentação de inúmeras atividades econômicas, a privatização de empresas estatais, as aquisições de empresas nacionais por grupos transnacionais, as empresas virtuais, além da existência do Código de Defesa do Consumidor, da integração do país ao mercado global, à sociedade em rede e à era da informação, tudo isso não permite mais a existência de um modelo arcaico de comunicação, calcado apenas na comunicação de fatos sociais e relevantes da organização, objetivo perseguido pela comunicação empresarial tradicional.

O papel que se espera da comunicação hoje vai mais além. Ela deve, efetivamente, servir de suporte para um modelo de gestão bem estruturado e com capacidade de levar a empresa a enfrentar os desafios cada vez mais competitivos de uma sociedade que se torna mais exigente em qualidade e em direitos. Da comunicação, espera-se que cumpra o seu verdadeiro papel social: o de envolver emissor e receptor em um diálogo aberto e democrático, em que a estratégia de gestão da empresa seja construída com base em princípios sociais e éticos.

A comunicação sem o compromisso estratégico dificilmente conseguirá legitimar-se no novo cenário competitivo, correndo sério risco de se manter irrelevante e trazer pouco ou nenhum valor para a estratégia global da organização. Nesse novo papel, a comunicação deixa de ser responsabilidade de um único órgão, setor ou departamento. Torna-se função de toda a instituição e incorpora-se, definitivamente, à gestão estratégica da organização.

Genelot (2001) afirma, de maneira categórica, que a comunicação é o motor de uma estratégia comum (a estratégia da empresa e a estratégia de comunicação como um ato único). Problematizando a questão da comunicação no ambiente da complexidade da organização, o autor sugere que a complexidade exige que se pense além dos parâmetros e das armadilhas do pensamento cartesiano (Morin e Le Moigne, 2000). Exige imaginar um sistema, ou melhor, um metassistema que exista independentemente do observador. Por essa razão, é necessário reconhecer, de uma vez por todas, o nível simbólico em que se processam os acontecimentos, procurando distinguir e entender como esses níveis ocorrem no mundo dos negócios.

O cenário da complexidade implica, para as organizações, um pensar diferenciado das situações que devem enfrentar para se manter com sucesso em seu ramo de atividade. Ao enfrentar um cenário de rápidas mudanças, fica evidente que a tradicional ferramenta do planejamento 
empresarial, principalmente o de longo prazo, perde eficiência, pois se a mudança é constante, ele tem de possuir uma enorme flexibilidade para poder acompanhá-la.

Genelot (2001) desenvolveu uma dimensão única para a estratégia da organização e a estratégia da comunicação e, para reforçar essa unidade, mostrou a evolução progressiva do conceito de estratégia nos últimos 40 anos, que esteve sob a pressão da complexidade, das incertezas e das turbulências de todos os tipos. Ele mostra que a passagem de uma visão planificadora da estratégia para uma visão de gerenciamento estratégico (pilotage managérial) e, depois, para uma reatividade (reativité) estratégica constitui uma ruptura conceitual, pois essa prática de gerenciamento leva em conta a dimensão da complexidade no ambiente das organizações e passa a considerar a comunicação um elemento essencial de gerenciamento estratégico.

Para viabilizar o gerenciamento estratégico, Genelot (2001) mostra a importância do desenvolvimento de uma consciência estratégica (conscience stratégique), afirmando que ela é possível quando o conjunto da coletividade partilha uma certa representação do futuro desejado. Todavia, a elaboração dessa visão estratégica compartilhada não pode ser realizada por imposição ou por decreto, pois a construção de representações partilhadas envolve aspectos complexos e delicados, tais como o processo de expressão e a negociação e apropriação de sentidos (Genelot, 2001). É aí que a comunicação organizacional deverá desempenhar seu papel, sem impor aos outros seu ponto de vista. Ela precisa fazê-lo por meio de conhecimentos compartilhados entre os participantes a fim de construir um projeto comum.

Nessa nova visão, mudam os papéis de quem exerce atividades de comunicação na organização: uma atividade que antes era concebida por especialistas da área passa a ser exercida de maneira compartilhada por diferentes profissionais. Podemos afirmar que a comunicação, no ambiente da complexidade, só irá concretizar o seu papel de ferramenta estratégica de gestão quando a empresa criar os verdadeiros canais para que a comunicação realize o seu princípio social básico, ou seja, o seu caráter democrático de permitir que todos os indivíduos possam compartilhar idéias, comportamentos, atitudes e, acima de tudo, a cultura organizacional. Esse caráter democrático se expressa por meio do diálogo e da produção de significados.

Genelot (2001) afirma que o mundo atual, caracterizado pela complexidade, não se surpreende com a busca do controle do sistema nervoso das organizações, cuja essência está na informação e na comunicação. Depois de ponderar que há uma certa "inflação verbal" em torno dos dois conceitos, mostra alguns dos termos a eles relacionados: profissões, técnicas, meios, suportes, sistemas e estratégias. Ele também reforça a idéia de que o termo co- 
municação pode cobrir diferentes sentidos, tais como processo, tecnologias/ mídias, telecomunicação, informática, interesses econômicos, ideologia etc. Como não existe uma definição cabal para esses conceitos, Genelot (2001) procura dar-lhes sentido, construindo uma aproximação entre ambos para sua aplicabilidade.

Quanto à informação, estabelece que seria relevante para as realidades complexas entender a informação como um conjunto de símbolos ou signos (sinais) na mesma linha daquilo que afirmavam Shannon e Weaver (1949) na sua teoria matemática da comunicação, que nada mais é do que uma teoria de sinais. Assim, para Genelot (2001), a informação é um conjunto de signos, símbolos, dados, mensagens que se pode conceber, emitir, transportar, receber e interpretar.

Alguns designam esse sentido de informação como "a informação racional". Todavia, para o autor, a informação não tem apenas esse sentido nominal, é também sensação ou significação. Em outras palavras, ela é “...a transformação do conhecimento que ela produz junto ao receptor" (Genelot, 2001:161). Aqui, ele recupera o sentido etimológico da palavra informar no sentido de "dar uma forma", como ocorre no ato de criação do escultor que dá uma forma àquilo que é informe. Para que uma informação tenha significado aos olhos de um receptor, ele afirma que é necessário o receptor encontrar a sensação dessa informação.

Assim, a informação, que ao mesmo tempo é sinal (signo), é também essa "forma", essa impressão, esse desejo de ação que ela engendra junto ao receptor. Para distinguir da "informação racional", alguns chamam de "informação relacional", ou subjetiva, essa ação do receptor de elaborar a sensação que o sinal lhe dá, incorporando sua subjetividade na informação. Essa distinção estabelecida por Genelot (2001) nos ajuda a compreender o papel dos indivíduos nas organizações e na sociedade da informação.

$\mathrm{O}$ aumento significativo de uma grande massa de informação que se torna a cada dia disponível às pessoas por diferentes meios tecnológicos não significa o aumento de informações úteis e portadoras de sensações. Pelo contrário, a multiplicação de sinais leva a uma perda de sensação. Aqui se identifica um paradoxo já que a quantidade de informação (dados e sinais) é percebida como um ruído. Aliás, Atlan (1979), em Le cristal et la fumée, definiu a crise atual como "a produção de ruído através da informação". É a situação de produção sem sentido, em oposição à situação de produção de sensação a partir do ruído que nos fala mais alto.

Nessa linha de reflexão, Genelot (2001) reforça a crítica de Robin (1989) à impossibilidade das tecnologias da informação, por elas mesmas, produzirem sinais, tornando-se conseqüentemente cada vez mais difícil para 
os receptores a percepção e a sensação, ou seja, torna-se cada vez mais difícil dar sensação a todos os sinais recebidos. Além dessa impossibilidade, Robin destaca a servidão a programas de comando que nós não havíamos realmente desejado e que estruturam nosso trabalho e nossa relação com o mundo contra nossa vontade.

Essa idéia é desenvolvida por Cohn que, partindo da imagem aristotélica da informação como "imposição de forma", afirma que a informação tem a ver com a imposição de forma e que essa imposição é da ordem da sobredeterminação. Para ele, “...o atributo da informação já não se aplica a determinadas técnicas, mas ao formato da sociedade como um todo" (Cohn, 2001:21). O autor mostra que a sociedade da informação é aquela cuja forma é sobredeterminada pela informação.

O sentido dado por Cohn (2001) à idéia de sobredeterminação é significativo. O primeiro ponto levantado que contraria o entendimento tradicional do tema é que a comunicação é distinta da informação e não é subordinada a ela como um de seus componentes. A idéia proposta é a de que a informação e a comunicação não compartilham do mesmo plano da "circulação" de significados, porque estão em níveis distintos. Enquanto a comunicação refere-se a conteúdos e a sua circulação, a informação não se refere a eles, mas sim ao modo como eles entram na comunicação e na circulação. Assim, enquanto a comunicação refere-se à transmissão de conteúdos, a informação refere-se à seleção deles. Essa idéia implica compreender a informação como atuante na esfera da produção dos conteúdos e não na esfera da circulação e, com isso, conferir à informação um caráter de produto resultante da ação humana em detrimento da visão tradicional que somente vê a informação na esfera da circulação como um mero dado. Genelot (2001) dá à informação um peso semelhante ao de Cohn, sem, contudo, fazer a distinção entre comunicação e informação.

Genelot (2001) destaca ainda o profundo descompasso entre a velocidade eletrônica que se processa em frações de segundo pelas tecnologias da informação e a formação de sensação que se dá de forma lenta e requer um diálogo interativo. Conseqüentemente, esse descompasso impossibilita o exercício de uma atividade reflexiva sobre os processos informativos. Portanto, para superar esses limites, é necessário reintroduzir a flexibilidade e a temporização nos circuitos eletrônicos sob a forma de mediadores humanos ou, como pondera Genelot (2001), é preciso deixar de apenas entender os signos de maneira formal para interpretá-los ao nível de uma nova lógica que permita sentir sensações. Ainda que o autor destaque o papel da informação na sociedade e nas organizações, ele vê na comunicação o instrumento que dá existência e coerência a qualquer sistema. Somente pela comunicação é possível estabelecer as in- 
tersecções e percepções das atividades compartilhadas. Ela é responsável pela "circulação de conteúdos".

Reforçando os aspectos da interação e compreensão pelos processos comunicativos, ele critica o comprometimento conceitual do termo comunicação com todo o conjunto de mídias e técnicas e não mais com um processo pelo qual "as pessoas se ouvem e se compreendem". Nesse ponto, Genelot (2001) se aproxima de maneira significativa da Teoria da Ação Comunicativa, na qual Habermas (1981) afirma que os indivíduos, além da competência, têm o desprendimento de agir para o estabelecimento do diálogo, tendo em vista a sua realização pessoal e coletiva. Esse diálogo se estabelece sobre fundamentos éticos e comportamentais. Para tornar possível a ação comunicativa, é necessário que todas as verdades anteriormente consideradas válidas e inabaláveis possam ser questionadas e que todas as normas sociais se tornem resultado de uma negociação na qual se busque o consenso pelo melhor argumento em um clima de respeito e reciprocidade.

Niklas Luhmann, sociólogo alemão, também defende uma proposta de comunicação dialógica, tentando substituir o conceito cibernético de informação pelo de significado. Todavia, essa tentativa é criticada por Habermas, que afirma a existência de uma incompatibilidade entre o conceitual sistêmico e toda a lógica que rege a categoria de significado. Em outros termos, Luhmann, ao introduzir a categoria de significados no ambiente sistêmico, pressupõe a possibilidade de uma interação dialógica dentro do sistema, em que valores e normas possam ser constituídos e questionados. Mas, para Habermas, o conceito cibernético não permite a constituição de significados da interação dialógica, pois estes são previamente estabelecidos e internalizados pelos atores que constituem o sistema. Por essa razão, Habermas não está convencido da praticabilidade do diálogo no ambiente sistêmico; ele acredita que o diálogo decorre da ação comunicativa entre atores sociais (Habermas e Luhmann, 1972).

Assim, para a ação comunicativa se realizar, segundo Habermas, são necessárias situações isentas de coação, em que se torne possível a comunicação plena, não distorcida, onde as "aspirações de validade" possam ser explicitadas, questionadas, confirmadas e asseguradas consensualmente. Esse é o objetivo a ser almejado em todos os níveis e em todas as áreas da sociedade moderna. Contudo, o próprio Habermas reconhece parecer utópico esse objetivo para a sociedade em geral. A fim de viabilizar a ação comunicativa, ele propõe uma espécie de institucionalização, ainda que marginalmente, da ação comunicativa em algumas estruturas do Lebenswelt (mundo vivido).

Por fim, vale a pena destacar que a ação comunicativa nada mais é que a necessidade dos seres humanos de se comunicarem por meio de um diálo- 
go argumentado. As argumentações são formas de comunicação quase extraordinárias e pressupõem muito mais que os relacionamentos humanos. O que Habermas traz de contribuição fundamental para se refletir sobre a comunicação organizacional, que se sustenta na base do diálogo, é que o processo comunicativo deve permitir a qualquer dos participantes da interação ou negociação poder e direitos iguais de questionar o outro sem recorrer à coerção, sendo necessário que suas argumentações sejam embasadas em racionalidade adequada ao contexto do evento. Essa igualdade de "poder e direitos" não significa simetria de desejos, conhecimentos, propósitos iguais ou posicionamentos, mas possibilidades e abertura na negociação para que possíveis diferenças e conflitos sejam expostos devidamente acompanhados das razões que os sustentam (Vizeu, 2003).

Genelot (2001), nessa linha habermasiana, reabilita o receptor em sua capacidade de produzir sentido e de desenvolver procedimentos de interpretação. O receptor, no desenvolvimento da sua competência de produzir sentido, interpreta o mundo vivido e o contexto cultural em que se apresentam os fenômenos, estabelecendo questionamentos e discussões e buscando significados da intencionalidade do sujeito diante da realidade. Quer-se com isso afirmar que o receptor é um agente ativo diante de mensagens recebidas e ele vai entendê-las de acordo com os seus valores, com o seu mundo social, com as suas leituras, experiências ou vivências.

Reforçando o papel ativo do receptor no processo de comunicação, Genelot (2001:172) afirma que "quando os sinais da comunicação vêm ao receptor, todo processo cognitivo entra em marcha para produzir um significado a partir desses sinais". Para o autor, o essencial no processo de comunicação se dá sempre no universo simbólico e social do receptor, construído por meio de atividades cognitivas, do ambiente social e das estruturas organizacionais. O significado da comunicação é dado, em última instância, pelo receptor.

\section{Conclusão}

O início do século XXI aponta para uma nova relação homem/organização/ mundo. Trata-se de uma relação que não leva em consideração apenas uma das dimensões do homem, a força de seu trabalho físico e mental. Por meio dessa nova relação, o homem é compreendido como um ser total e que pensa criticamente, age eficiente e eficazmente e sente-se criativamente como parte do todo e como o todo da parte. 
A organização, para estabelecer essa nova relação, deve se constituir como um espaço de interação dialógica e precisa estar pautada em abordagens que privilegiam a visão macroambiental, onde o crescimento pessoal seja uma constante; a liderança seja uma característica fundamental; a noção de cidadão-consumidor ganhe maior consistência e o aperfeiçoamento da prática esteja respaldado na pluralidade de teorias. Enfim, nessas novas abordagens, a qualidade de vida seja um objetivo primordial.

A imagem pública das organizações passou a representar um fator estratégico tão importante quanto os produtos e serviços. As empresas querem ser reconhecidas não apenas por sua marca ou por suas atividades específicas, mas por sua atuação como empresas cidadãs. Nesse contexto, a comunicação ocorrerá não mais por meio de algo que se diz para um mercado passivo, mas pela qualidade das relações que serão estabelecidas com esses atores e pela credibilidade gerada por uma rede de relações articulada pela empresa com seus clientes, funcionários, fornecedores etc.

A comunicação organizacional vem assumindo uma nova dimensão estratégica nas organizações que, como se vê, modifica paulatinamente antigos limites. A comunicação assume um papel muito mais abrangente, fazendo referência a tudo que diz respeito à posição social e ao funcionamento da organização, que envolve desde seu clima interno até suas relações institucionais. As empresas precisam abrir portas, reduzir desconfianças e iniciar um diálogo - sem limites - com os formadores de opinião, o que só será possível se as opiniões e posturas da sociedade forem levadas em conta.

Num ambiente de incertezas e complexidade, é necessário compreender a estratégia organizacional não mais como um exercício de previsão conduzido por um grupo limitado de experts, mas sim como um processo de emergência estratégica envolvendo toda a coletividade, em cujo centro está a comunicação.

Não é mais possível conceber e executar planos, projetos e programas isolados de comunicação institucional, mercadológica, de administração interna ou externa, pois uma estratégia comunicacional integra todos os setores da organização e envolve todos os seus participantes. No pensamento de Genelot (2001), essa estratégia teria mais destaque do que a própria estratégia geral da organização, já que é por meio dos dispositivos de comunicação que as pessoas ou grupos expressam o sentido que querem dar à sua ação, confrontam seus pontos de vista e compreendem as dificuldades e as oportunidades. Sem dúvida, essas não são atividades fáceis, pois os processos comunicativos são, às vezes, fragmentados, negociados (para se alcançar o consenso, segundo Habermas), investidos de emoção e sentimentos e articulados entre pontos que ora se opõem, ora se complementam. Todavia, os dispositivos comunicacionais condicionarão a amplitude do engajamento das pessoas na rea- 
tividade estratégica. Se a estratégia de comunicação for utilitária, limitada, eminentemente instrumental, exclusivamente descendente, as pessoas não se reconhecerão mais aí e darão pouco ou o mínimo de si mesmas. Se, ao contrário, for uma comunicação aberta, receptiva, interativa, haverá chance de engajamento e participação.

A grande inovação de Genelot (2001) para a área das organizações é, sem dúvida, pensar na estratégia de comunicação organizacional como um ato único em relação à estratégia geral da organização. Como ato único, a estratégia organizacional não se prende a um objetivo a ser alcançado, mas a um processo de reatividade generalizada, que supõe uma consciência estratégica que certamente nos levará a refletir sobre os aspectos que transcendem a estratégia propriamente dita e isso implica considerarmos "...os fenômenos de auto-organização, as questões éticas e o debate sobre os graus de liberdade deixados ao homem pelas estruturas que ele próprio construiu" (Genelot, 2001:307).

Genelot (2001) nos sugere que a estratégia de comunicação organizacional agrega valores, possibilita a integração de grupos e pessoas e produz mediações significativas das organizações com seus diferentes públicos (mercado, opinião pública e sociedade em geral). A comunicação desempenha, portanto, nesse processo de mudanças gerenciais e organizacionais num ambiente de complexidade, um papel significativo, pois envolve a troca consciente de mensagens entre interlocutores, sendo fator essencial de convivência e elemento determinante das formas que a sociabilidade humana assume. Conseqüentemente, os modelos e estruturas organizacionais devem estabelecer uma estratégia de comunicação dialógica, participativa e competente, na qual os participantes envolvidos se tornem "atores" de um processo que se realiza pelas múltiplas mediações que se manifestam nas relações do(s) sujeito(s) com a organização e dessa com a sociedade. Desse modo, entender a comunicação como um processo de mediação é admitir que ela envolve intercâmbios entre entidades heterogêneas de ordem material, imaterial e comportamental. Daí a necessidade de se repensá-la acentuando a dimensão da interdependência e da flexibilidade nas organizações.

Vale a pena, nessa mesma direção, destacar o discurso de Braman (1989:239) que, definindo a informação como uma força constitutiva na sociedade, pondera: "a informação não é afetada somente por seu ambiente, mas ela própria afeta os outros elementos do ambiente. A informação não é aquilo que está somente embutida numa estrutura social, mas ela mesma é criadora da estrutura".

Tanto a visão de Genelot (2001) como a de Braman (1989) contrapõem-se às tendências teóricas que legitimam fortes componentes tayloristas 
e fordistas em suas formas de organização e justificam conteúdos positivistas que preservam o enrijecimento das concepções hierárquicas e, conseqüentemente, o fortalecimento do poder de maneira elitista e autoritária. Em tais tendências, a comunicação serve como elemento opressor e controlador de comportamentos, ainda que revestida de modernidade ao privilegiar a dimensão técnica, e mesmo a revolução telemática que, embora amplie incomensuravelmente, no tempo e no espaço, a transmissão de informação - letras e números - pela utilização de sinais magnéticos e óticos, não serve para entendermos o significado maior da transformação tecnológica, que é a instauração de um novo padrão organizacional no qual as estratégias de comunicação comprometidas com a crítica da qualidade e com a eficácia da informação levem em consideração a ética nos negócios e os valores nobres do ser humano que fundamentam e estruturam a sociedade.

\section{Referências bibliográficas}

ALVESSON, M. Communication, power and organization. Berlin: Walter de Gruyer, 1996.

ARGYRIS, C. et al. Comunicação eficaz na empresa. Rio de Janeiro: Campus, 1999.

ATLAN, H. Le cristal et la fumée. Paris: Éditions du Seuil, 1979.

BRAMAN, S. Defining information: an approach for policymakers. Telecommunications Policy, v. 13, n. 3, p. 233-242, Sept. 1989.

CARDOSO, O. O. Os paradigmas no ensino da comunicação - a transgressão epistemológica. Comunicação \& Sociedade, ano 10, n. 17, p. 9-32, ago. 1991.

CASALI, A. M. Comunicação organizacional: considerações epistemológicas. In: ENCONTRO NACIONAL DOS PROGRAMAS DE PÓS-GRADUAÇÃO EM ADMINISTRAÇÃO ENANPAD, 28., Curitiba, 2004. Anais... Curitiba: Enanpad, 2004.

CASTELLS, M. A era da informação: economia, sociedade e cultura - a sociedade em rede. 4. ed. São Paulo: Paz e Terra, 1997. v. 1.

CASTRO, G. (Org.). Ensaios de complexidade. Porto Alegre: Sulina, 1997.

COHN, G. A forma da sociedade da informação. In: DOWBOR, L. et al. (Orgs.). Desafios da comunicação. Petrópolis: Vozes, 2001. p. 20-27.

DANIELS, T. D.; SPIKER, B.; PAPA, M. Perspectives on organizational communication. Dubuque: Brown \& Benchamark, 1997.

DANTAS, M. A lógica do capital - informação: a fragmentação dos monopólios e a monopolização das fragmentações num mundo de comunicações globais. Rio de Janeiro: Contraponto, 1996. 
DAVENPORT, T. H. Ecologia da informação — por que só a tecnologia não basta para o sucesso na era da informação. São Paulo: Futura, 1998.

ECO, H. Lector in fábula. São Paulo: Perspectiva, 1986.

ESCARPIT, R. L'information et la communication. Paris: Hachette Livre, 1991.

FOSSÁ, M. I. T. Os desafios da comunicação empresarial na era da qualidade - o caso Xerox. 1997. Dissertação (Mestrado em Comunicação Social) — Programa de Pós-Graduação em Comunicação, IMS, São Bernardo do Campo.

GENELOT, D. Manager dans la complexité - reflexions à l'usage des dirigents. 3. ed. Paris: Insep Consulting, 2001.

GOODMAN, M. Corporate communication for executives. New York: State University of New York Press, 1998.

HABERMAS, J. Theorie des kommunikativen handelns. Frankfurt: Suhrkamp Verlag, 1981. v. 2.

; LUHMANN, N. Gesellschaftstheorie oder sozialtechnologie. Frankfurt: Suhrkamp Verlag, 1972.

KUNSCH, M. M. K. Relações públicas e modernidade — novos paradigmas na comunicação organizacional. São Paulo: Summus, 1997.

LASTRES, H. M. M.; ALBAGLI, S. (Orgs.). Informação e globalização na era do conhecimento. Rio de Janeiro: Campus, 1999.

LÉVY, P. As tecnologias da inteligência: o futuro do pensamento na era da informática. Rio de Janeiro: Editora 34, 1996.

. Cibercultura. 2. ed. São Paulo: Editora 34, 2000.

LOJKINE, J. A revolução informacional. São Paulo: Cortez, 1995.

LUHMANN, N. Die wissenschaft der gesellschaft. Frankfurt: Suhrkamp Verlag, 1990.

MCGEE, J.; PRUSAK, L. Gerenciamento estratégico da informação: aumente a competitividade de sua empresa utilizando a informação como uma ferramenta estratégica. Rio de Janeiro: Campus, 1995.

MATTELART, A. Comunicação - mundo: história das idéias e das estratégias. 2. ed. Petrópolis: Vozes, 1994.

MINTZBERG, H.; BRIAN, Q. O processo da estratégia. Porto Alegre: Bookman, 2000.

MORIN, E.; LE MOIGNE, J. L. A inteligência da complexidade. São Paulo: Peirópolis, 2000.

OLIVEIRA, D. P. R. Sistemas de informações gerenciais: estratégicas, táticas e operacionais. 5. ed. São Paulo: Atlas, 1992. 
PUTNAM, L. L.; Paradigms for organizational communication research: an overview and synthesis. The Western Journal of Speech Communication, v. 46, n. 2, p. 192-206, 1982.

—; PHILLIPS, N.; CHAPMAN, P. Metáforas da comunicação e da organização. In: CLEGG, S. R.; HARDY, C.; NORD, W. R. (Orgs.). Handbook de estudos organizacionais: ação e análises organizacionais. São Paulo: Atlas, 2004. v. 3, p. 77-125.

REGO, F. G. Torquato do. Comunicação empresarial, comunicação institucional. São Paulo: Summus, 1986.

RIEL, C. B. M. Principles of corporate communication. London: Prentice Hall, 1995.

ROBIN, J. Changer d'ère. Paris: Éditions du Seuil, 1989.

ROCCO JUNIOR, A. J. A comunicação na era das organizações em rede: o falar e o escutar como ferramentas estratégicas de gestão. 2000. Dissertação (Estudos Pós-Graduados em Administração) — PUC, São Paulo.

RODRIGUES, A. D. Estratégia da comunicação, questão comunicacional e formas de sociabilidade. Lisboa: Presença, 1990.

SANDRONI, P. Dicionário de administração e finanças. São Paulo: Best Seller, 1996.

SANTOS, B. S. Introdução a uma ciência pós-moderna. Rio de Janeiro: Graal, 1989.

SCHULER, M. (Org.). Comunicação estratégica. São Paulo: Atlas, 2004.

SCROFERNEKER, C. M. A. Perspectivas teóricas da comunicação organizacional. GT Comunicação Organizacional da Intercom, set. 2000.

SHANON, C.; WEAVER, W. The mathematical theory of communication. Urbana: University of Illinois Press, 1949.

SHAPIRO, C.; VARIAN, H. R. A economia da informação: como os princípios econômicos se aplicam à área da internet. São Paulo: Campus, 1999.

SILVA, J. R. G.; OLIVEIRA, M. C. L. A composição de um quadro de referência para a gestão da comunicação organizacional. In: ENANPAD, 27., Atibaia, 2003. Anais... Atibaia: Enanpad, 2003.

TAYLOR, J. R. Rethinking the theory of organizational communication: how to read an organization. Norwood, NJ: Ablex, 1993.

TOMPKINS, P. K.; WANCA-THIBAULT, M. Organizational communication: prelude and prospects. In: JABLIN, F. M.; PUTNAM, L. L. (Eds.). The new handbook of organizational communication: advances in theory, research and methods. London: Sage, 2001.

VIZEU, F. Algumas contribuições da teoria da ação comunicativa para a área de organizações. In: ENANPAD, 27., Atibaia, 2003. Anais... Atibaia: Enanpad, 2003. 